\title{
EXPERIMENTAL INVESTIGATION ON EFFECT OF MINERAL ADMIXTURES ON HIGH PERFORMANCE CONCRETE WITH VARIOUS W/B RATIOS
}

\author{
Shaikh Mohd Zubair ${ }^{1}$, S.S. Jamkar ${ }^{2}$ \\ ${ }^{1}$ ME Student, Department of Applied Mechanics, Government Engineering College; Aurangabad \\ ${ }^{2}$ Professor, Department of Applied Mechanics, Government Engineering College; Aurangabad, 431005
}

\begin{abstract}
Now a day's high performance concrete is globally used in the infrastructure industry for strong and durable structure, to produced high performance concrete various supplementary cementitious material are used as mineral admixture. This research involves the use of Fly ash, Alccofine and Silica fume at various proportions to enhance the compressive strength of high performance concrete. the investigation was carried out by replacing $10 \%$ fly ash along with $17 \%$ of alccofine and $10 \%$ fly ash along with $17 \%$ of silica fume by weight of cementitious material. To cover a wide range of compressive strength of concrete various water binder ratio (W/b) of $0.25,0.3$ and 0.35 were used. The effect of various parameters such as percentage replacement of mineral admixture, water to binder ratio and corresponding compressive strength is studied on fresh and hardened state of concrete. The study mainly consisted of establishing relation between these parameters graphically. Investigation demonstrates that alcofine performs batter than that of silica fume along with fly ash in fresh and harden state of concrete.
\end{abstract}

Keywords: High Performance Concrete, Fly Ash, Alccofine, Silica Fume, workability, Compressive strength

\section{INTRODUCTION}

HPC is a material which is being used by infrastructure industry for long term performance strong, durable structures, better rheological, mechanical and durability properties than normal strength concrete. The general mix design guideline given by either American concrete institute (ACI-211-4R) ,departmental of environmental science (DOE Method), recommend that design of highstrength concrete mixtures is possible by keeping water binder ratio as much as possible to keep low as per the requirement. it is always better that high strengths are made possible by reducing porosity by keeping water binder ratio low ,maintaining homogeneity, and reducing shrinkage in the hydrated cement paste and the transition zone. ACI defined high-performance concrete as a concrete satisfying special requirement of long term performance and durability requirements that cannot always be achieved significantly by using conventional practices and normal mixing, placing, and curing methods.

generally Mineral admixtures are used in order to improve mechanical properties of the mixture because of its compatibility with various type of cement along with Pozzolanic nature, self cementitious activity based performance. although, mineral admixtures help to decrease cost of the mixture by improving the workability of fresh concrete. Moreover, fresh concrete mixtures containing mineral admixtures are less prone to bleeding, segregation as well as help to produced cohesive concrete which ultimately increase the durability of the structure. The effect of mineral admixtures on the properties of mortar, fresh concrete along with hardened concrete mixtures was studied by many researchers. Moreover, there is relatively acute data on the microstructure of the binders subjected to various deleterious effects. Although there is no specific point of separation between high-strength concrete and normal-strength concrete, as per the Indian Standard guideline suggest high-strength concrete as concrete with a compressive strength greater than fifty five N/mm ${ }^{2}$ For mix proportioning of HSC may or may not require special materials, but it definitely requires materials having highest quality and their optimum proportions. The utilization of HSC that consistently fulfill requirements for workability and strength development. it posses more durability as well as reduced permeability for better performance of the structure used as a modern construction martial by infrastructure industry. It would be difficult to produce highstrength concrete mixtures with required workability without using chemical admixtures particularly high range water reducing admixture. For validation of strength to water/cement ratio for normal strength concrete and high strength concrete the target water/cement ratio can be in the range $0.2-0.5$.

\section{SYSTEM DEVELOPMENT FOR STUDY}

High Performance concrete is prepared with help of the guideline give by ACI-211-4R and in accordance with IS10262-2009, by using various cementitious martial like Fly Ash, Silica fume, Alccofine as a mineral admixture. various $\mathrm{w} / \mathrm{b}$ ratio is used for achieving the different compressive 
strength of concrete and its relative workability. Concrete cubes of $100 \mathrm{~mm}$ size were made for concrete mix proportioned to replace $10 \%, 17 \%$, and $17 \%$ cement with fly ash, Silica Fume and Alccofine respectively. To achieve different compressive strength of concrete wide range of concrete mixes with water to binder ratio $(\mathrm{W} / \mathrm{b})$ of 0.25 , 0.3 and 0.35 were used.. The dosages of super plasticizer keep constant throughout the work as $0.1 \%$ by mass of total cementitious material. when concrete is in plastic state i.e. fresh concrete workability is measured in terms of slump and compacting factor. while harden concrete is tested for compressive strength with the help of compression testing machine.

\section{DESIGN DATA CONSIDERED FOR} PROPORTIONING

a) Type of cement: OPC 53 grade, IS 8112 .

b) Nominal maximum size of aggregate: $12.5 \mathrm{~mm}$

c) Exposure condition: Moderate

d) Degree of supervision: Good

e) Type of aggregate: Crushed angular

f) Chemical admixture: S.P. $0.1 \%$ by mass of total cementitious material

\section{Materials Test Data}

a) Cement used: OPC 53 grade.

b) Specific gravity of

1) Cement: 3.15

2) Coarse aggregate: 2.89

3) Fine aggregate: 2.83

c) Water absorption:

1) Coarse aggregate: $1.38 \%$

2) Fine aggregate: $1.15 \%$

d) Free moisture:

1) Coarse aggregate: NIL

2) Fine aggregate: NIL

e) Sieve analysis:

1) Coarse aggregate: Confirming to IS 383.

Fine aggregate: confirming to Zone-I Confirming to IS 383
Table 1: Physical Properties of Ordinary Portland Cement (OPC)

\begin{tabular}{|c|c|c|}
\hline $\begin{array}{l}\text { Sr. } \\
\text { No. }\end{array}$ & Description of Test & Results \\
\hline 01 & $\begin{array}{l}\text { Fineness of cement ( residue on } \\
\text { IS sieve No. } 9 \text { ) }\end{array}$ & $5.89 \%$ \\
\hline 02 & Specific gravity & 3.15 \\
\hline 03 & $\begin{array}{l}\text { Setting time of cement } \\
\text { a) } \quad \text { Initial setting time } \\
\text { b) } \\
\text { Final setting time }\end{array}$ & $\begin{array}{l}150 \\
\text { minute } \\
\text { 380minute }\end{array}$ \\
\hline 04 & $\begin{array}{l}\text { Soundness test of cement (with } \\
\text { Le-Chatelier's mould) }\end{array}$ & $0.5 \mathrm{~mm}$ \\
\hline 06 & $\begin{array}{l}\text { Compressive strength of cement } \\
\text { (a) } 3 \text { days } \\
\text { (b) } 7 \text { days } \\
\text { (c) } 28 \text { days }\end{array}$ & $\begin{array}{l}35.8 \\
\mathrm{~N} / \mathrm{mm}^{2} \\
47 \mathrm{~N} / \mathrm{mm}^{2} \\
68 \mathrm{~N} / \mathrm{mm}^{2}\end{array}$ \\
\hline
\end{tabular}

Alccofine- Alccofine 1203 is proprietary low calcium silicate based mineral additive Controlled granulation process results in unique particle size distribution. Alccofine has particle range 4 to 6 microns, average particle size is 4 micron.

Table: 2. Physical Properties of Alccofine

\begin{tabular}{|l|l|l|}
\hline Property & Unit & Value \\
\hline Average Particle Size & Micron & 4 to 6 \\
\hline Fineness & $\mathrm{Cm} 2$ / gm & 12500 \\
\hline Specific Gravity & ----- & 2.86 \\
\hline Bulk Density & $\mathrm{Kg} / \mathrm{M} 3$ & 600 to 700 \\
\hline
\end{tabular}

Fly Ash- Fly ash used as cementitious material is a product of DIRK India Private ltd Maharashtra, India confirming to IS-3812-part I and is of pozzocrete P100grade of class F, physical properties of P100 shown in

Table 3

\begin{tabular}{|c|c|c|c|c|}
\hline Test & Unit & IS- Specification & \multicolumn{2}{|c|}{ Typical Test Result } \\
\hline $\begin{array}{l}\text { Fineness - Specific Surface by Blaine's } \\
\text { Permeability Method(Min.) }\end{array}$ & $\mathrm{m} 2 / \mathrm{kg}$ & 320 & \multicolumn{2}{|l|}{638} \\
\hline ROS \# 500(25 MIC) Max. & $\%$ & NOT SPECIFIED & \multicolumn{2}{|l|}{0.08} \\
\hline ROS \# 350(45 MIC) Max. & $\%$ & 34 & \multicolumn{2}{|c|}{ Traces } \\
\hline Lime Reactivity(Minimum) & $\mathrm{N} / \mathrm{mm} 2$ & 4.5 & \multicolumn{2}{|l|}{8.60} \\
\hline Moisture Content(Max.) & $\%$ & 2 & \multicolumn{2}{|l|}{0.27} \\
\hline Autoclave Expansion(Max.) & $\%$ & 0.8 & \multicolumn{2}{|l|}{0.024} \\
\hline Compressive Strength At 28 days - & \multirow[t]{4}{*}{$\mathrm{N} / \mathrm{mm} 2$} & \multirow[t]{4}{*}{$\begin{array}{l}80 \% \text { of strength of } \\
\text { plain cement mortar } \\
\text { cubes (min.) }\end{array}$} & & \\
\hline \multirow[t]{2}{*}{ Pozzocrete + Cement Mortar } & & & 52 & $102.56 \%$ \\
\hline & & & \multirow[t]{2}{*}{50.7} & \\
\hline Plain Cement Mortar & & & & \\
\hline
\end{tabular}




\begin{tabular}{|l|l|l|l|}
\hline Chemical Analysis & & & \\
\hline Test & $\%$ & IS- Specification & \\
\hline Loss on Ignition (Max.) & $\%$ & 5 & 0.80 \\
\hline $\mathrm{SiO}_{2}+\mathrm{Al}_{2} \mathrm{O}_{3}+\mathrm{Fe}_{2} \mathrm{O}_{3}$ & $\%$ & 70 min. by mass & 93.42 \\
\hline $\mathrm{SiO}_{2}$ & $\%$ & 35 min. by mass & 58.3 \\
\hline $\mathrm{MgO}$ & $\%$ & 5 max. by mass & 1.70 \\
\hline $\mathrm{SO}_{3}$ & $\%$ & 3.0 max.by mass & 0.65 \\
\hline $\mathrm{Na}_{2} \mathrm{O}$ & $\%$ & 1.5 max. by mass & 0.56 \\
\hline Total Chlorides & $\%$ & 0.05 max by mass & 0.024 \\
\hline
\end{tabular}

Silica Fume- Silica Fume used for the work is of Grade 920 D and obtained from ELKEM South Asia Pvt. Ltd.. The silica fume was partially replaced for cement, conforming to ASTM C1240. It is available in dry densified form. The density and specific gravity was found to be 672 $\mathrm{kg} / \mathrm{m} 3$ \& 2.2 respectively. physical properties of P100 is shown in table no:4

\section{Table: 4}

\begin{tabular}{|l|l|}
\hline $\begin{array}{l}\text { Mandatory Chemical and } \\
\text { Phisical Requirements }\end{array}$ & $\begin{array}{l}\text { Specification as } \\
\text { per ASTM C } \\
\mathbf{1 2 4 0}\end{array}$ \\
\hline Sio2 $(\%)$ & $>85$ \\
\hline Fineness $\left(\mathrm{cm}^{2} / \mathrm{gm}\right)$ & 1950 \\
\hline Moisture $(\%)$ & $<3$ \\
\hline Bulk Density $(\mathrm{kg} / \mathrm{m} 3)$ & 678 \\
\hline Retain on 45 Micron sieve $(\%)$ & $<10$ \\
\hline
\end{tabular}

Superplastisizer- superplasticizer used was a new generation Polycarboxyle base super plasticizer containing carboxylic $(\mathrm{COOH})$ group instead of sulphonic $\left(\mathrm{SO}_{3} \mathrm{H}\right)$ as in case of Melamine or naphthalene formaldehyde sulphonate. It appear deep brown colour with 50\% solid content and a specific gravity of 1.11 with chloride content below $0.02 \%$. The superplasticizer was added in all mixes and the quantity was kept constant throughout the study as $1 \%$ by weight of total cementitious material.

Fine aggregates- Locally available river sand was used as fine aggregate. The sand used was having fineness modulus 2.9. confirmed to grading zone-I as per IS: 383-1970 specification.

Table 5: Mix Proportions Containing Alccofine with different water to Cement ratios.

\begin{tabular}{|c|l|l|l|l|l|l|l|}
\hline & $\begin{array}{l}\text { Cement } \\
\text { Kg/m3 }\end{array}$ & $\begin{array}{l}\text { Alccofine } \\
\text { Kg/m3 }\end{array}$ & $\begin{array}{l}\text { Fly ash } \\
\text { Kg/m3 }\end{array}$ & $\begin{array}{l}\text { Fine } \\
\text { aggregate } \\
\text { Kg/m3 }\end{array}$ & $\begin{array}{l}\text { Coarse } \\
\text { aggregate } \\
\text { Kg/m3 }\end{array}$ & $\begin{array}{l}\text { Water } \\
\text { (lit) }\end{array}$ & $\begin{array}{l}\text { Chemical } \\
\text { Admixture } \\
\text { Kg/m3 }\end{array}$ \\
\hline $\begin{array}{c}\text { M-1 } \\
\text { W/b =0.25 }\end{array}$ & 407.16 & 54.288 & 81.432 & 683.01 & 1073.58 & 157.455 & 5.4288 \\
\hline $\begin{array}{c}\text { M-2 } \\
\text { W/b=0.3 }\end{array}$ & 339.3 & 45.24 & 67.83 & 718.532 & 1132.05 & 158.636 & 4.524 \\
\hline $\begin{array}{c}\text { M-3 } \\
\text { W/b=0.35 }\end{array}$ & 290.82 & 38.777 & 58.1657 & 740.18 & 1167.68 & 159.355 & 3.8777 \\
\hline
\end{tabular}

Table 6: Mix Proportions Containing Silica fume with different water to Cement ratios.

\begin{tabular}{|c|c|c|c|c|c|c|c|}
\hline & $\begin{array}{c}\text { Cement } \\
\mathrm{Kg} / \mathrm{m} 3\end{array}$ & $\begin{array}{c}\text { Silica fume } \\
\mathrm{Kg} / \mathrm{m} 3\end{array}$ & $\begin{array}{c}\text { Fly ash } \\
\mathrm{Kg} / \mathrm{m} 3\end{array}$ & $\begin{array}{c}\text { Fine aggregate } \\
\mathrm{Kg} / \mathrm{m} 3\end{array}$ & $\begin{array}{c}\text { Coarse } \\
\text { aggregate } \\
\mathrm{Kg} / \mathrm{m} 3\end{array}$ & $\begin{array}{c}\text { Water } \\
\text { (lit) }\end{array}$ & $\begin{array}{c}\text { Chemical } \\
\text { Admixture Kg/m3 }\end{array}$ \\
\hline $\begin{array}{c}\text { M-1 } \\
\mathrm{W} / \mathrm{b}=0.25\end{array}$ & 407.16 & 54.288 & 81.432 & 683.01 & 1073.58 & 157.455 & 5.4288 \\
\hline $\begin{array}{c}\mathrm{M}-2 \\
\mathrm{~W} / \mathrm{b}=0.3\end{array}$ & 339.3 & 45.24 & 67.83 & 718.532 & 1132.05 & 158.636 & 4.524 \\
\hline $\begin{array}{c}\mathrm{M}-3 \\
\mathrm{~W} / \mathrm{b}=0.35\end{array}$ & 290.82 & 38.777 & 58.1657 & 740.18 & 1167.68 & 159.355 & 3.8777 \\
\hline
\end{tabular}


Table 7: 7 Days Compressive Strength Results

\begin{tabular}{|c|c|c|c|c|}
\hline Mix & W/B Ratio & Composition & Individual Cube Strength (Mpa) & 7 Days Compressive Strength (Mpa) \\
\hline \multirow{3}{*}{ M1 } & \multirow{3}{*}{0.25} & \multirow{3}{*}{ Alccofine + Fly ash } & 62 & \multirow{3}{*}{60.5} \\
\hline & & & 55.5 & \\
\hline & & & 64 & \\
\hline \multirow{3}{*}{ M1 } & \multirow{3}{*}{0.25} & \multirow{3}{*}{ Silica fume + Fly ash } & 62 & \multirow{3}{*}{58} \\
\hline & & & 48 & \\
\hline & & & 64 & \\
\hline \multirow{3}{*}{ M2 } & \multirow{3}{*}{0.3} & \multirow{3}{*}{ Alccofine + Fly ash } & 49 & \multirow{3}{*}{47} \\
\hline & & & 48 & \\
\hline & & & 44 & \\
\hline \multirow{3}{*}{ M2 } & \multirow{3}{*}{0.3} & \multirow{3}{*}{ Silica fume + Fly ash } & 48 & \multirow{3}{*}{45} \\
\hline & & & 44 & \\
\hline & & & 43 & \\
\hline \multirow{3}{*}{ M3 } & \multirow{3}{*}{0.35} & \multirow{3}{*}{ Alccofine + Fly ash } & 46 & \multirow{3}{*}{42.5} \\
\hline & & & 42.5 & \\
\hline & & & 39 & \\
\hline \multirow{3}{*}{ M3 } & \multirow{3}{*}{0.35} & \multirow{3}{*}{ Silica fume + Fly ash } & 45 & \multirow{3}{*}{41} \\
\hline & & & 40 & \\
\hline & & & 48 & \\
\hline
\end{tabular}

Table 8: 28 Days Compressive Strength Results

\begin{tabular}{|c|c|c|c|c|}
\hline Mix & W/B Ratio & Composition & Individual Cube Strength (Mpa) & Compressive Strength (Mpa) \\
\hline \multirow{3}{*}{ M1 } & \multirow{3}{*}{0.25} & \multirow{3}{*}{ Alccofine + Fly ash } & 89 & \multirow{3}{*}{79} \\
\hline & & & 75 & \\
\hline & & & 79 & \\
\hline \multirow{3}{*}{ M1 } & \multirow{3}{*}{0.25} & \multirow{3}{*}{ Silica fume + Fly ash } & 63 & \multirow{3}{*}{76} \\
\hline & & & 58 & \\
\hline & & & 53 & \\
\hline \multirow{3}{*}{ M2 } & \multirow{3}{*}{0.3} & \multirow{3}{*}{ Alccofine + Fly ash } & 52 & \multirow{3}{*}{64} \\
\hline & & & 43 & \\
\hline & & & 46 & \\
\hline \multirow{3}{*}{ M2 } & \multirow{3}{*}{0.3} & \multirow{3}{*}{ Silica fume + Fly ash } & 65 & \multirow{3}{*}{61} \\
\hline & & & 55 & \\
\hline & & & 57 & \\
\hline \multirow{3}{*}{ M3 } & \multirow{3}{*}{0.35} & Alccofine + Fly ash & 62 & \multirow{3}{*}{58} \\
\hline & & & 59 & \\
\hline & & & 53 & \\
\hline \multirow{3}{*}{ M3 } & \multirow{3}{*}{0.35} & Silica fume + Fly ash & 59 & \multirow{3}{*}{53} \\
\hline & & & 52 & \\
\hline & & & 48 & \\
\hline
\end{tabular}




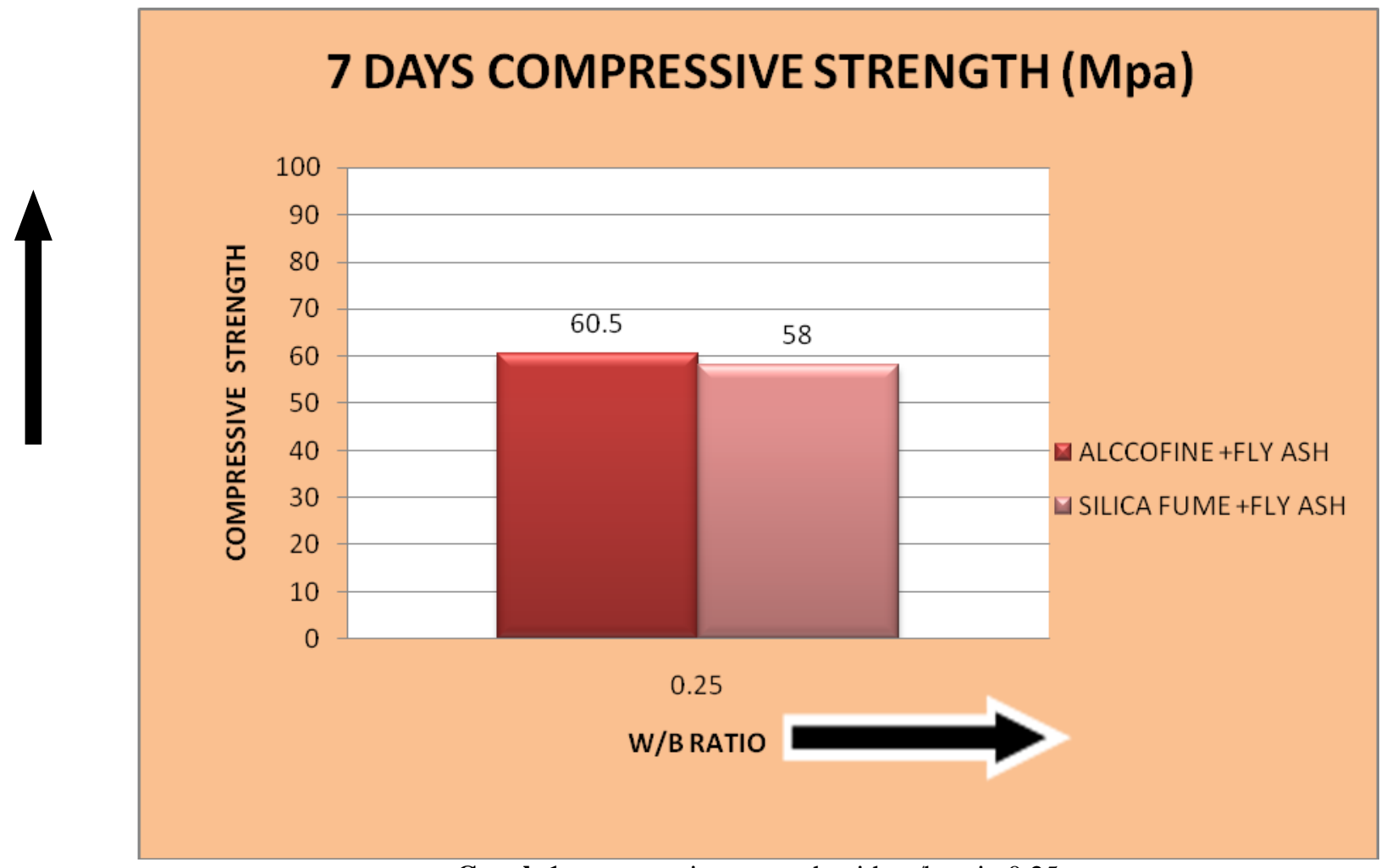

Graph 1: compressive strength with $w / b$ ratio 0.25

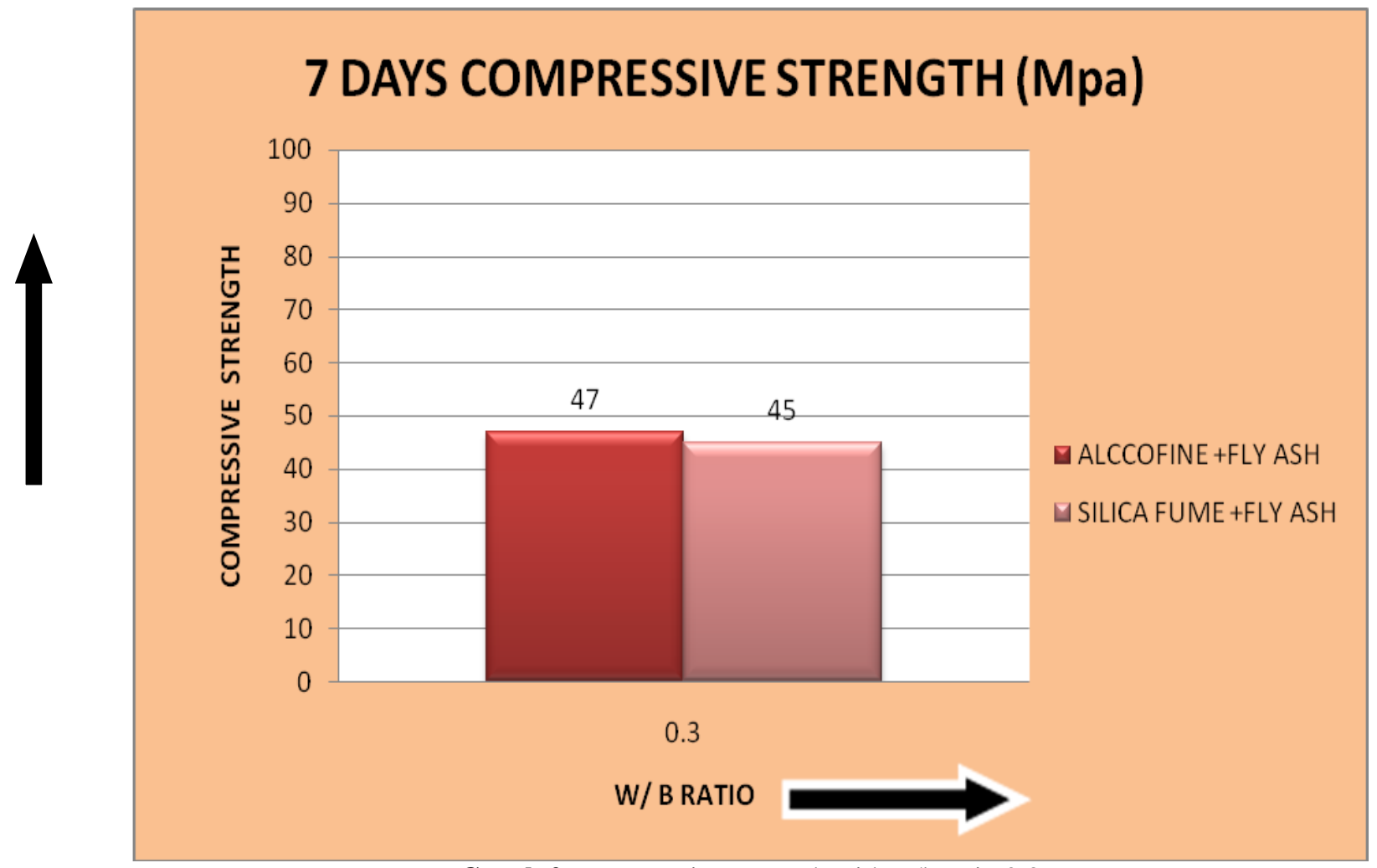

Graph 2: compressive strength with w/b ratio 0.3 


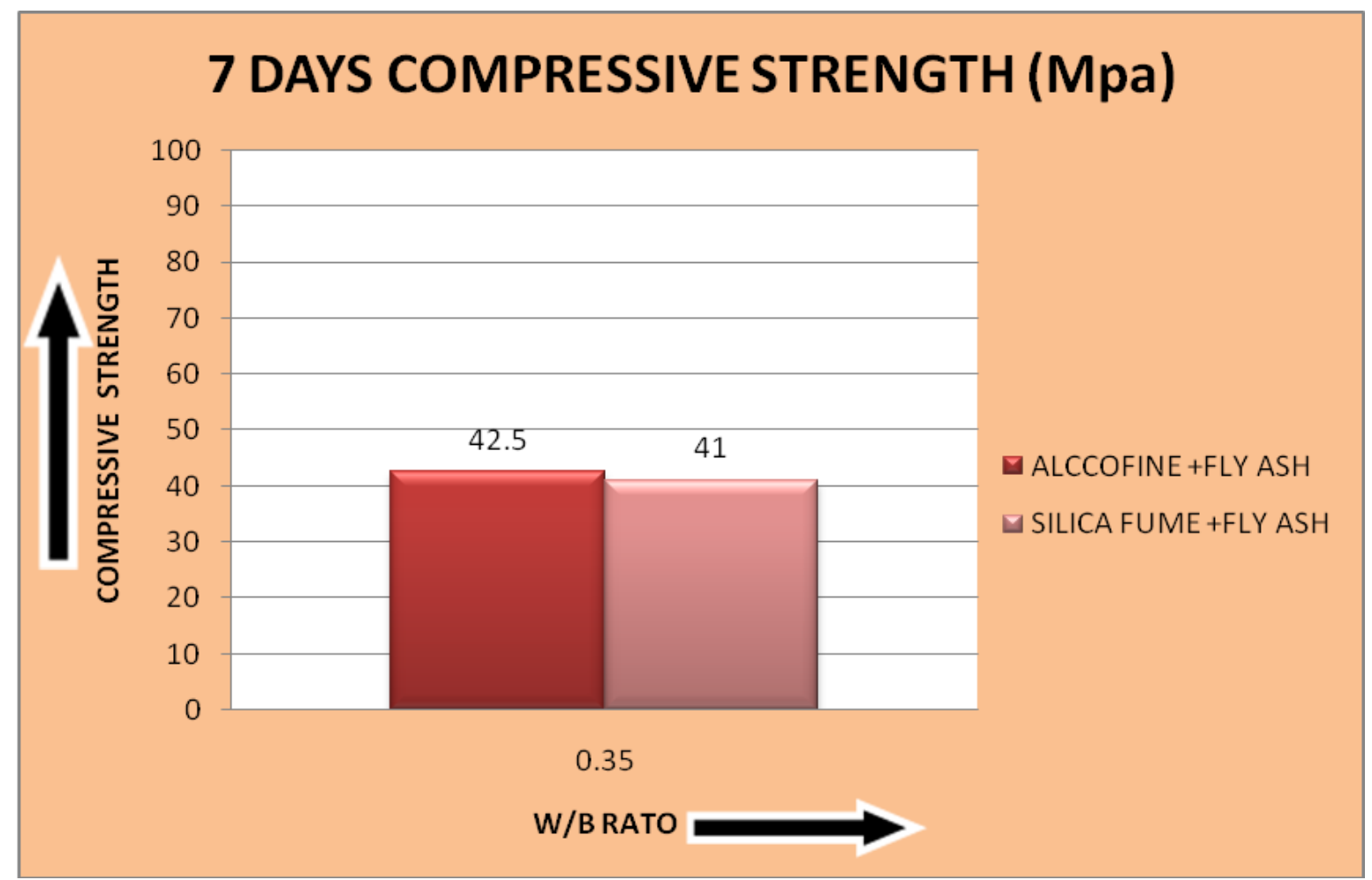

Graph 3: compressive strength with w/b ratio 0.35

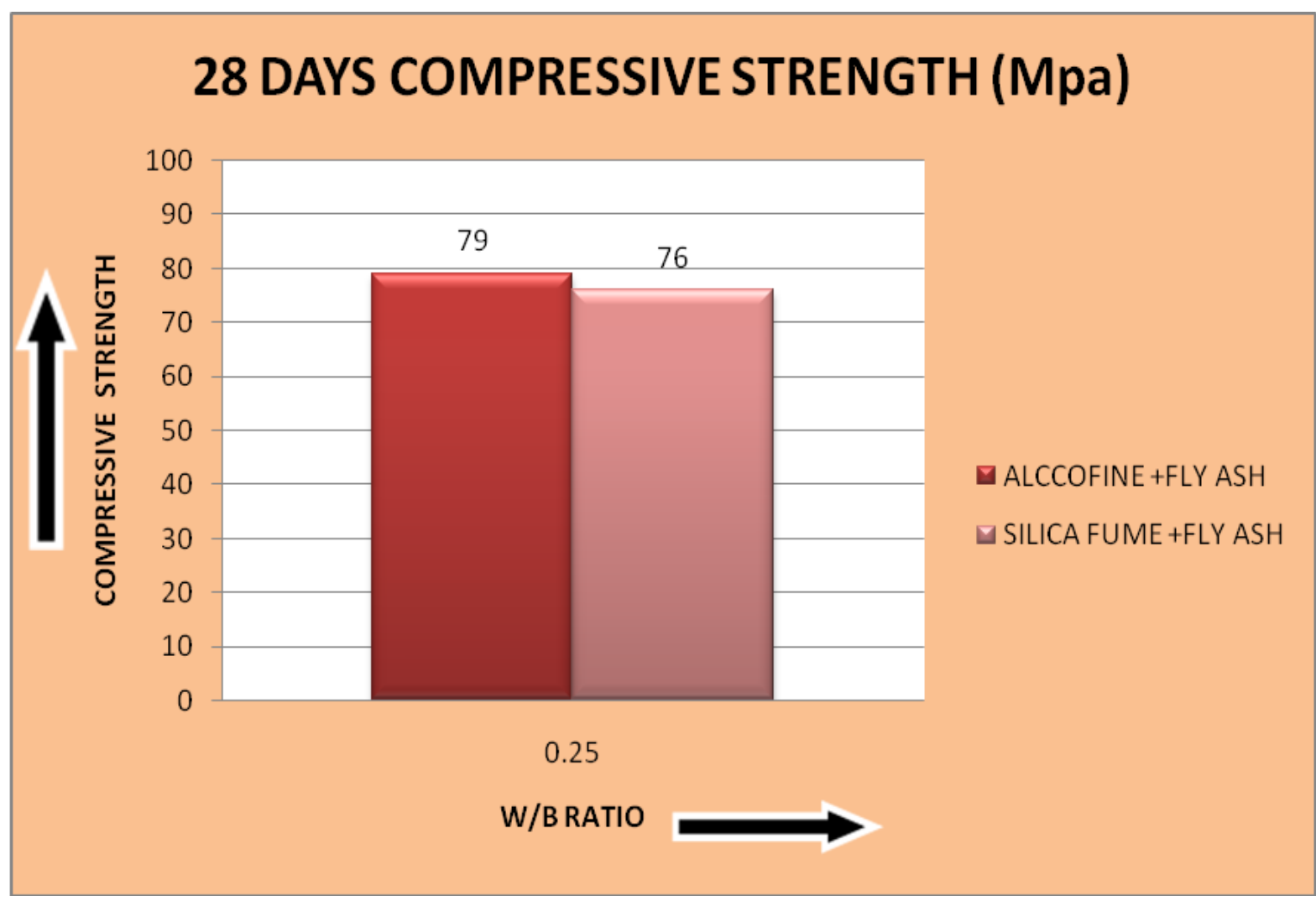

Graph 4: compressive strength with w/b ratio 0.25 


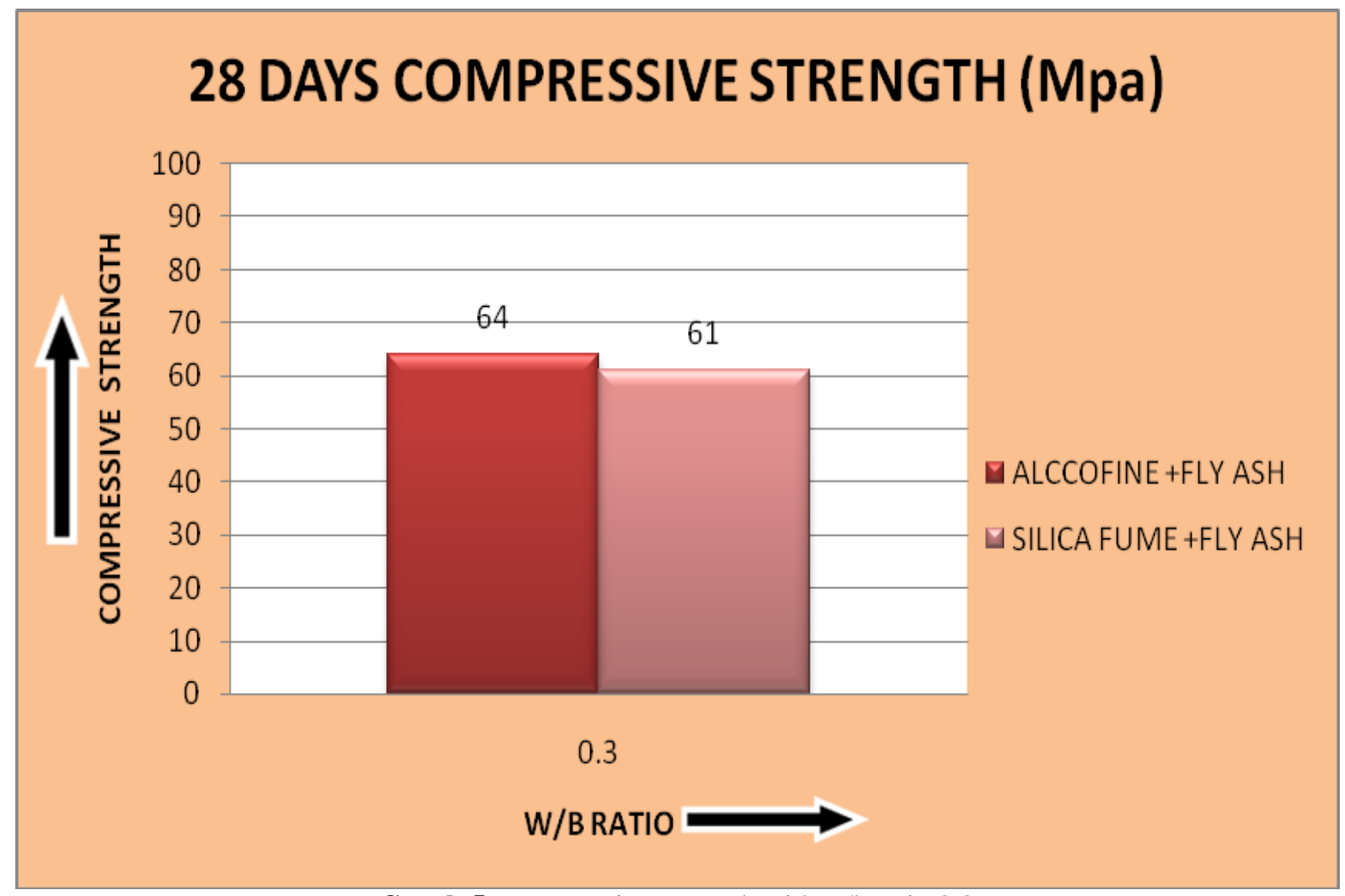

Graph 5: compressive strength with w/b ratio 0.3

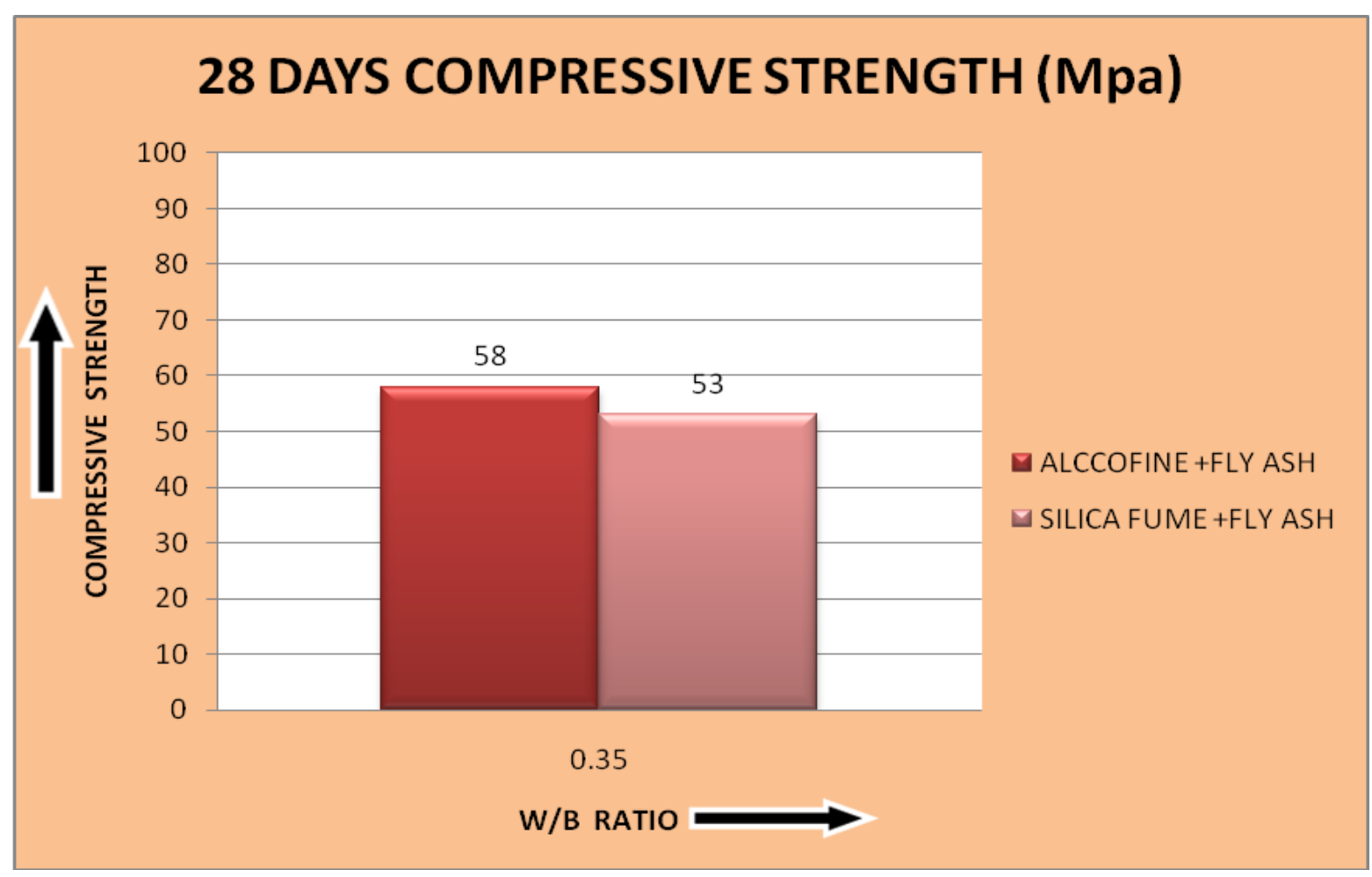

Graph 6: compressive strength with w/b ratio 0.35 


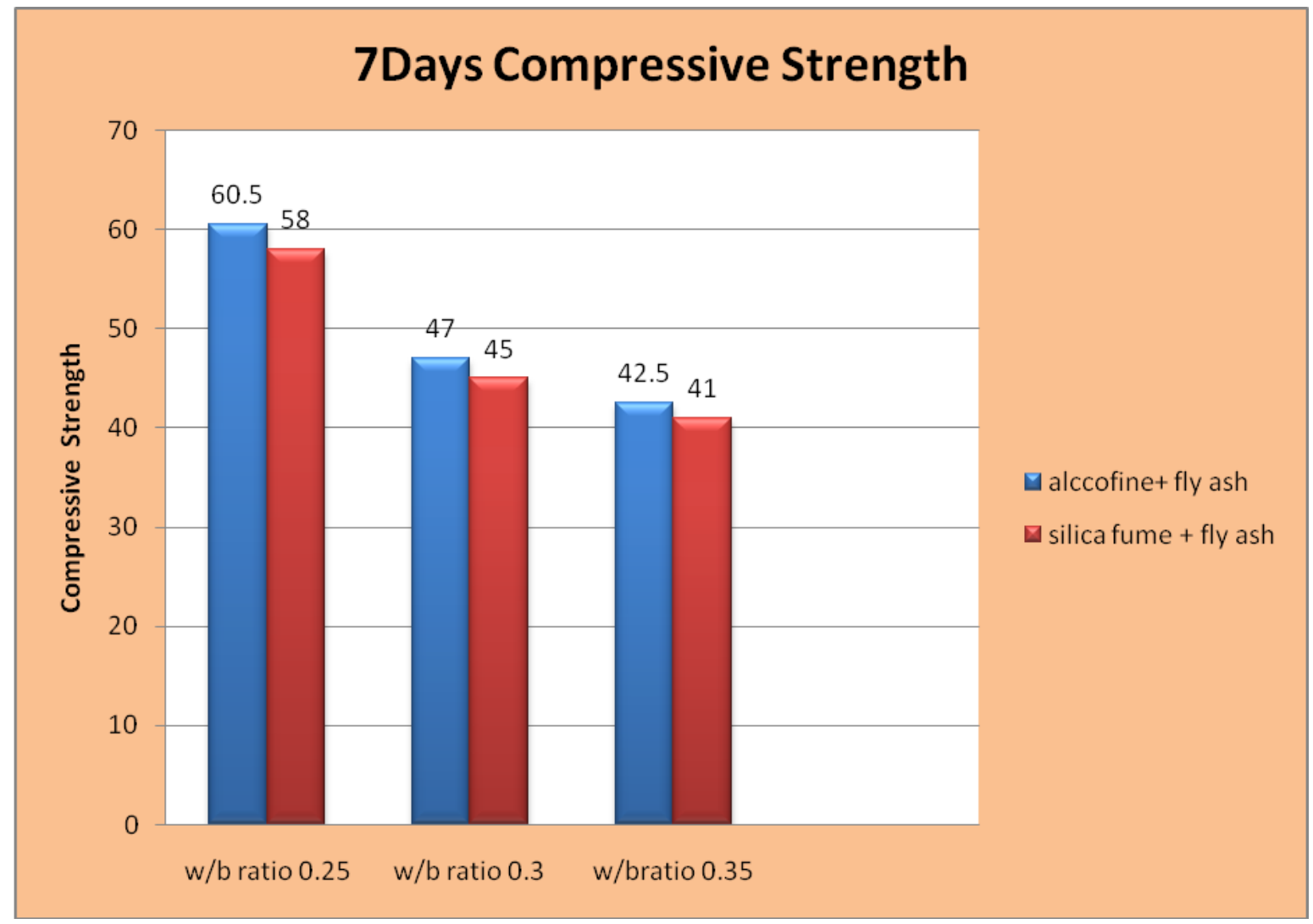

Graph 7: 7 Days Compressive Strength Comparative Graph .

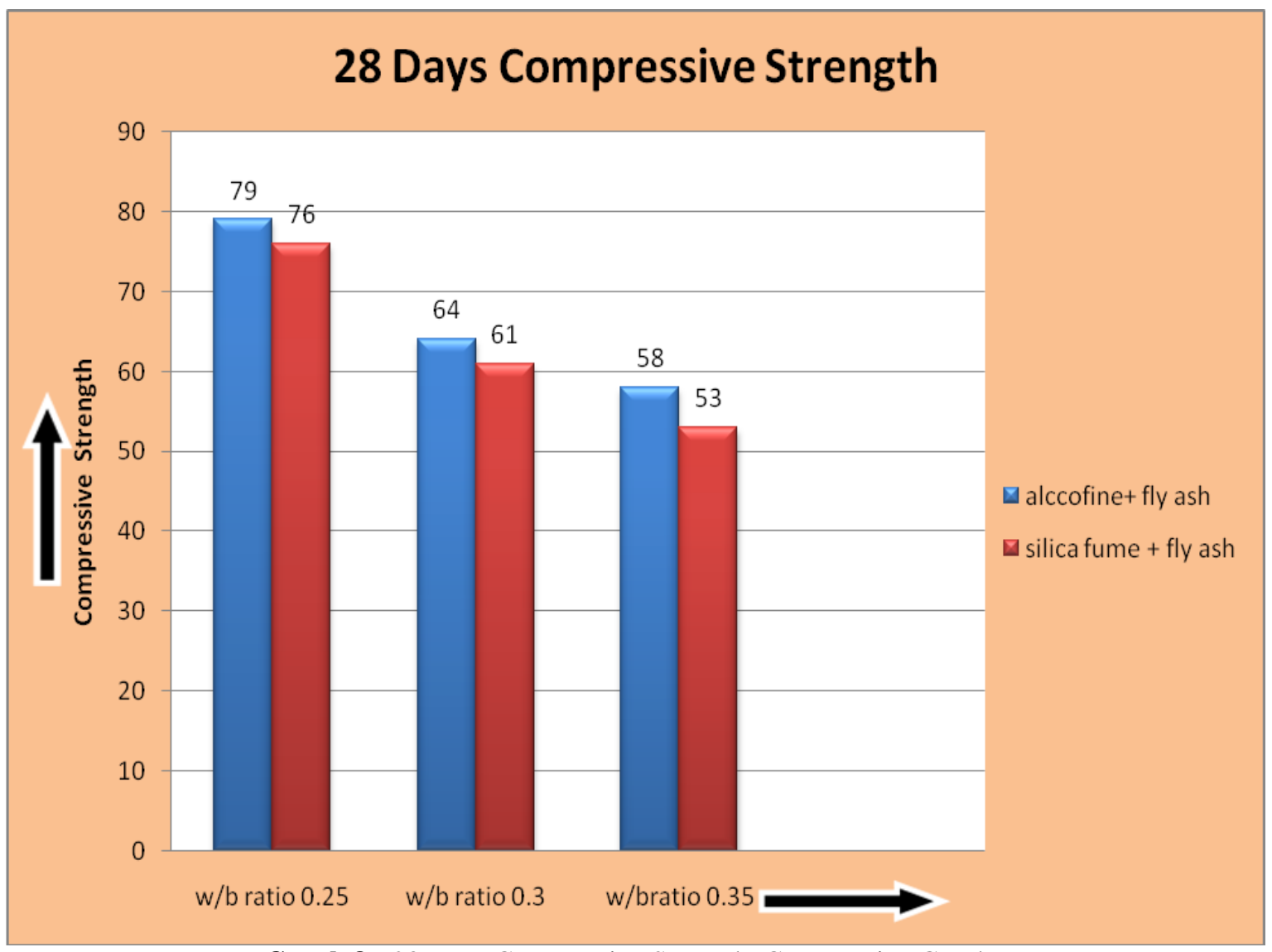

Graph 8: 28 Days Compressive Strength Comparative Graph . 


\section{CONCLUSION}

After carrying out compressive strength test on casted cubes at specified days the results obtained concludes that the mix having combination of alccofine and fly ash has maximum compressive strength as compare to silica fume and fly ash based concrete.

the compressive strength of concrete containing different amount of water content, are within +/- 15 percent of average value.Based on this experimental work it conclude that the workability of alcofine and fly ash based concrete is more. the properties of silica fume and alccofine, the silica fume has finer particles than alcofine thus it is less workable and it required more dosage of superplastisizer to achieve the workability same as alcofine. Higher the content of silica fume lower is degree of workability. It demands higher dosage of water-reducing admixtures or super plasticizers in order to keep water demand similar to that of reference mix.

\section{REFERENCES}

[1] ACI code 211.4R-08: "Guide or selecting proportions for HSC using Portland cement and other cementitious material."

[2] IS 10262: 2009 "Indian standard concrete mix proportioning guidelines" (First Revision).

[3] IS 383, "Specifications for Coarse and Fine Aggregates from Natural Source of Concrete," Bureau of Indian standard New Delhi, 1982.

[4] IS: 516-1959, Edition 1.2 (1991-07), "Indian Standard for Methods of test for strength of concrete

[5] "Short-Term Mechanical Properties of High-Strength Concrete" by Andrew Logan, Wonchang Choi, Amir Mirmiran, Sami Rizkalla, and Paul Zia, ACI Materials Journal, Title no. 106-M46.

[6] "Mechanical Properties of High Strength Concrete Using Fly Ash" by Ali Elheber Ahmed Elshekh, Nasir Shafiq etc. IEEE Journal 2013.

[7] "Effects of various tests on mechanical properties of high strength concrete" by 1Alireza Mokhtarzadeh And Catherine E. French (2002)

[8] "Considerations in producing high strength concrete" by Mohammad Abdur Rashida and Mohammad Abul Mansurb, Journal of Civil Engineering (IEB), 37(1) (2009) 53-63.

[9] Effect of W/C Ratio on Workability and Mechanical Properties of High Strength Self Compacting Concrete (M70 Grade)" by Mallikarjuna Reddy V, Seshagiri Rao M V, International Journal of Engineering Research and Development may 2013.

[10] "Effect on compressive and flexural strength of highperformance concrete incorporating alccofine and fly ash" by P. J. PATEL \& H. S. PATEL, International Journal of Civil, Structural, Environmental and Infrastructure Engineering Research and Development (IJCSEIERD). Feb 2013.

[11] "High strength concrete containing natural pozzolan and silica fume" by M.J. Shannag, Elsevier Science Ltd, Cement \& Concrete Composites 22 (2000).
[12] "Studying the effects of Fibers and Mineral Admixtures on High Strength Concrete" by Jayie Shah, Prof. Ashita Sheth, International Journal of Innovative Research in Advanced Engineering (IJIRAE) Volume 1 Issue 4 (May 2014).

[13] "Comparison of fly ash, silica fume and metakaolin from mechanical properties and durability performance of mortar mixtures view point" Ali Mardani-Aghabaglou, Gözde Inan Sezer, Kambiz Ramyar, Construction and Building Materials (2014).

[14] "An experimental investigation on effect of ggbs and glass fibre in high perfomance concrete" by Dr. P.Muthupriya, ternational Journal of Civil Engineering and Technology (IJCIET), (Aug.2013).

[15] "Design of m100 grade concrete (aci method)" by sreenivasulu and k. srinivasa rao, global J. of Engg. \& Appl. Sciences, (2012).

[16] "Effect of Alccofine on Self Compacting Concrete" by M.S. Pawar, A.C. Saoji, the International Journal Of Engineering And Science (IJES) (2013).

[17] "A new mix deign method for high performance concrete" by a. islam laskara and s. talukdar, asian journal of civil engineering (building and housing) vol. 9, no. 1 (2008).

[18] S.Bhaskar, Ravindra Gettu, B.H.Bharatkumar and M.Neelamegam, "Strength, Bond and Durability Related Properties of Concretes with Mineral Admixtures", The Indian Concrete Journal, February 2012, pp.-.09-15

[19] C. Freeda Christya and D. Tensing, "Effect of ClassF Fly Ash as Partial Replacement with Cement and Fine Aggregate in Mortar" Indian Journal of Engineering \& Materials Sciences, Vol. 17, April 2010, pp. 140-144.

[20] J. Prabakar, P. Devadas and M. Neelamegam, "Effect of Fly Ash on Durability and Performance of Concrete" the Indian concrete journal, Vol. 85, No. 11, November 2011, pp. 9-15. 